\title{
New data on Anthaxia (Anthaxia) lucens Küster, 1852 (Buprestidae Coleoptera) in the proposed extension of In- violata Regional Park and its presence in Latium (Central Italy)
}

\author{
Edoardo Pulvirentil ${ }^{1,2,}$, Francesco Cervoni ${ }^{1,2}$ \& Daniele Marini ${ }^{1,3}$ \\ ${ }^{1}$ Associazione Naturalistica Valle dell'Aniene (ANVA), Via delle Ginestre 30, 00012 Guidonia Montecelio (Rome), \\ Italy \\ ${ }^{2}$ Società Romana di Scienze Naturali (SRSN), Via Fratelli Maristi 43, 00137 Rome, Italy \\ ${ }^{3}$ Environmental Toxicology, Department of Organismal Biology, EBC, Uppsala Universitet, Norbyvägen 18A, 75236 \\ Uppsala, Sweden. ORCID: 0000-0002-7197-6196 \\ *Corresponding author, e-mail: edowikipedia@gmail.com
}

\begin{abstract}
The occurrence of Anthaxia (Anthaxia) lucens Küster, 1852 (Coleoptera Buprestidae) in Inviolata Regional Park (Latium) has been recently reported in a checklist. Here we describe these observations and we add new records for this population in the locality of Tor Mastorta. Furthermore, we show data of a new site, approximately $2 \mathrm{~km}$ in a straight line from the latter one, still in the Municipality of Guidonia Montecelio (Rome). These two locations, together with another population in Segni (Rome), constitute three new spots for this species in Latium, for which only extremely ancient data were available. Moreover, the presence of the species within the proposed extension boundaries of the aforementioned Park supports the upgrade validity of this protected area.
\end{abstract}

KEY WORDS Conservation; distribution update; Guidonia Montecelio; jewel beetle; protected area.

Received 22.01.2021; accepted 12.02.2021; published online 26.04.2021

\section{INTRODUCTION}

Anthaxia (Anthaxia) lucens Küster, 1852 was described from specimens collected in "Dalmatia bei Ragusa" (currently Dubrovnik, southern Croatia) (Küster, 1852).

The larval development of this saproxylic beetle occurs in dead wood of Prunus dulcis (Mill.) D.A. Webb. The adult is found on Asteraceae inflorescences and on Rosa spp. (Gobbi, 1986), differing from its close congener A. candens (Panzer, 1793) which is not a flower-visitors species (Hanot \& San Martin, 2019). Anthaxia lucens is widespread across the eastern Mediterranean: western Turkey, Greece (Mühle et al., 2000), Crete, Hungary, former Yugoslavia, Albania, Bulgaria, Central-Southern Italy, Sicily, Malta (Curletti, 1994, as A. candens lucens), and it is also reported in Macedonia and Germany (Bolu \& Özgen, 2011).

This jewel beetle (Buprestidae) is considered LC (Least Concern) in the Red List of Italian saproxylic Coleoptera (Audisio et al., 2014).

In Italy (Fig. 1), A. lucens is largely present in Apulia and Sicily (Curletti, 1994). It is ascertained in few localities of Calabria and Basilicata (Melito di Porto Salvo: Tassi, 1962; Accettura and 
Miglionico: Curletti, 1994; Apromonte and Pollino Massif: Angelini, 2020), and it has been reported by both Luigioni (1929) and Porta (1929) in Campania. Curletti (1994) was the first to highlight its occurrence in Abruzzo and Molise (Campobasso), while Sakalian and collegues (2020) have reported different locations for the Municipality of Ortona dei Marsi in the National Park of Abruzzo, Lazio and Molise. In addition, a specimen from the hamlet of Capodacqua is signalled in the Forum Entomologi Italiani (Capestrano, AQ, 14.05.2013, leg. A. Morelli, det. M. Gigli by photo, Alessio Morelli collection, Pescara) and its presence is confirmed for Monte Morrone (Ofena, AQ; A. Morelli, in litteris). The northernmost site in Italy for this jewel beetle appears to be San Martino d'Ocre (AQ; CKmap datum: Curletti, 2005).

In Latium, only two specimens from Ronciglione municipality (VT, UTM squares $10 \times 10$ km: 33T UG68, UG69 \& UG78), currently belonging to the Vallon collection (Civic Museum of Zoology in Rome), were known. They were collected at the end of the 19th century and Gobbi (1993) placed them among the uncertain data. In contrast, Curletti (1994) does not mention any locality for the region. Anthaxia lucens has been recently mentioned in the Insect checklist of Inviolata Park (Latium) by Crucitti and colleagues (2019a), as a new species for Latium Region.

In this paper all occurrence data of this jewel beetle for Latium are reported, clarified and summarized (Fig. 2).

\section{MATERIAL AND METHODS}

All the specimens were found on inflorescences or bred from fallen almond branches. The first samples of each site were manually collected and determined by stereomicroscopy, whereas the others were captured, immediately identified and released in the field.

A WGS84 geographic coordinate system (decimal degrees) with a UTM $3233 \mathrm{~N}$ projection has been used.

The research activities in the Parco Naturale Regionale Archeologico dell'Inviolata (Inviolata Park - Italian official list of protected areas: EUAP1032 - Fig. 3) were carried out with the authorizations of the Ente Parco Naturale Regionale dei Monti Lucretili (managing body of the above-mentioned protected area since the issuance of Regional Law 64/16 [L.R. 64/16]) issued to Società Romana di Scienze Naturali (SRSN) in the period 2016-2019 (Protocollo d'Intesa - XI. 2016) and to Associazione Naturalistica Valle dell'Aniene (ANVA) in 2020 (Prot. $\mathrm{n}^{\circ}$ 606, Palombara Sabina, 18.02.2020).

ABBREVIATIONS. ANVAC (ANVA collection, Guidonia Montecelio, Italy); DB (Daniele Baiocchi collection, Rome, Italy); MG (Maurizio Gigli collection, Rome, Italy); FR (Federico Rosso collection, Turin, Italy).

\section{RESULTS AND DISCUSSION}

\section{Anthaxia (Anthaxia) lucens Küster, 1852}

Material examined. Guidonia Montecelio (Rome, Italy), Tor Mastorta (41.981278, 12.694750 - UTM squares 10x10 km: 33T UG05), on Asteraceae inflorescences along a country track exposed to strong sunlight, 25.05.2017, leg. F. Cervoni \& L. Santoboni, det. M. Gigli (by photo), 1 ex. (ANVAC); Guidonia Montecelio, Tor Mastorta $(41.978664,12.695030 ; 41.982463$, 12.694777 - UTM squares $10 \times 10 \mathrm{~km}: 33$ T UG04 \& UG05), on Asteraceae inflorescences along a country track exposed to strong sunlight, 28.05.2017, leg. E. Pulvirenti, det. M. Gigli (by photo), 2 exx. (ANVAC); Segni (Rome, Italy), Porta Saracena (UTM square 10x10 km: $33 \mathrm{~T}$ UG31 - G. Bartolomei, pers. comm.), photographic data from Forum Natura Mediterraneo, 19.05.2019, leg. G. Bartolomei, det. G. Pezzi (by photo); Guidonia Montecelio, field between Via Aureliano and Via della Pietrara in the locality of Quarto di Tor Mastorta (41.995093, 12.708902 UTM square 10x10 km: 33T UG15), eclosion from branches of $P$. dulcis, 05.2020, leg. L. Santoboni; det. E. Pulvirenti, 5 exx. (ANVAC; FR; Fig. 4); Guidonia Montecelio, Tor Mastorta (41.977312, 12.694841 - UTM squares 10x10 km: 33T UG04), on Rosa sp., 03.06.2020, leg. \& det. M. Gigli \& D. Baiocchi, 2 exx (DB; MG).

The species was found and identified by the authors with capture and release method on the dates 11.06.2017, 19.06.2017, 19.05.2018 in Tor Mastorta locality. 


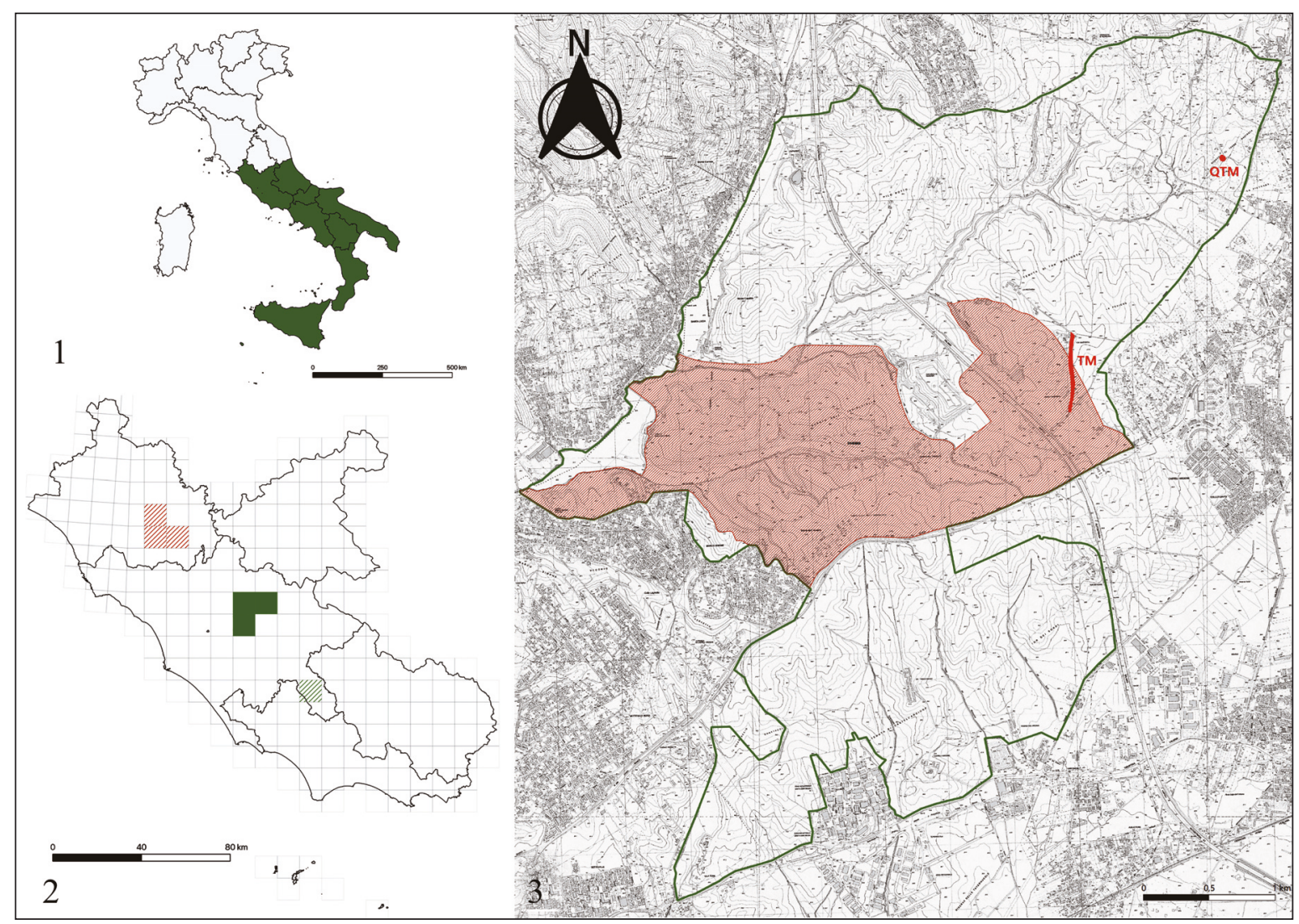

Figure 1. Distribution of Anthaxia lucens by Italian regions according to the data reported in this paper (green: presence; GIS software: QGIS). Figure 2. Map of Latium Region divided by UTM squares 10x10 km indicating ancient data (red squares), recent data (green squares), approximate data (observations/specimen from a locality or municipality - squares filled with oblique lines) and precise data (georeferenced observations/specimen - fully coloured squares) of this Buprestidae (UTM grid from ornitho.it; GIS software: QGIS). Figure 3. Map of Inviolata Park (red oblique lines: current area; red perimeter: current boundaries; green perimeter: proposed boundaries) in which presence sites of this jewel beetle (red areas: TM: Tor Mastorta; QTM: Quarto di Tor Mastorta) are shown (modified from Proposta di Legge n. 245 del 5 ottobre 2020, Consiglio Regionale del Lazio).

Biology. The discovery site in the Tenuta di Tor Mastorta (private property on the eastern edge of the Inviolata Park) consists of a cart track that runs alongside ancient abandoned farmhouses (Fig. 5). This path is lined with some plants of Prunus dulcis, Rosa sp., and Anacyclus radiatus Loisel. ssp. radiatus (M. Giardini det. 2017) (Figs. 6, 7), on whose inflorescences the adults of $A$. lucens feed together with A. (Haplanthaxia) millefolii polychloros Abeille de Perrin, 1894. Moreover, the cart track is subjected to the passage of ovine herds and agricultural vehicles, while the surrounding area is composed of the typical Roman Campagna landscape, with grazing and cultivated fields with wheat and olive trees. Within these lands are interspersed small gallery scrubs, denser in correspondence with the ditches, consisting chiefly of Acer campestre L., Corylus avellana L., Quercus cerris L., Q. robur L. and Ulmus minor Mill. (Giardini, 2005).

The site placed between Via Aureliano and Via della Pietrara, in locality of Quarto di Tor Mastorta, is situated inside a private small parcel scattered with fruit trees.

The presence of A. lucens around Porta Saracena (Segni - G. Bartolomei, pers. comm.) was not highlighted by the authors, therefore biological details describing the site cannot be provided.

REMARKS. Tor Mastorta site partially belongs to Inviolata Park (for approx. 375 m), while Quarto di Tor Mastorta site is approximately $2 \mathrm{~km}$ outside this Regional Park (Fig. 3). 
Nonetheless, the two spots are positioned completely within a protected landscape area, the MiBACT (Ministero per i beni e le attività culturali e per il turismo - Italian Ministry of Cultural Heritage and Activities) landscape constraint called "Area delle tenute storiche di Tor Mastorta, di Pilo Rotto, dell'Inviolata, di Tor dei Sordi, di Castell'Arcione e di alcune località limitrofe (Area of the historic estates of Tor Mastorta, Pilo Rotto, Inviolata, Tor dei Sordi, Castell'Arcione and some adjecent localities)", declared of considerable public interest with the ministerial decree of 16 September 2016 (DM 16/09/2016 del MiBACT). With the bill n. 245 of 5 October 2020 (Proposta di Legge n. 245 del 5 ottobre 2020), assigned to the VIII Commission Agriculture, environment of the Lazio Regional Council (VIII Commissione - Agricoltura, ambiente del Consiglio Regionale del Lazio), it is proposed and intended to expand the boundaries of the Inviolata Park almost entirely according to the model

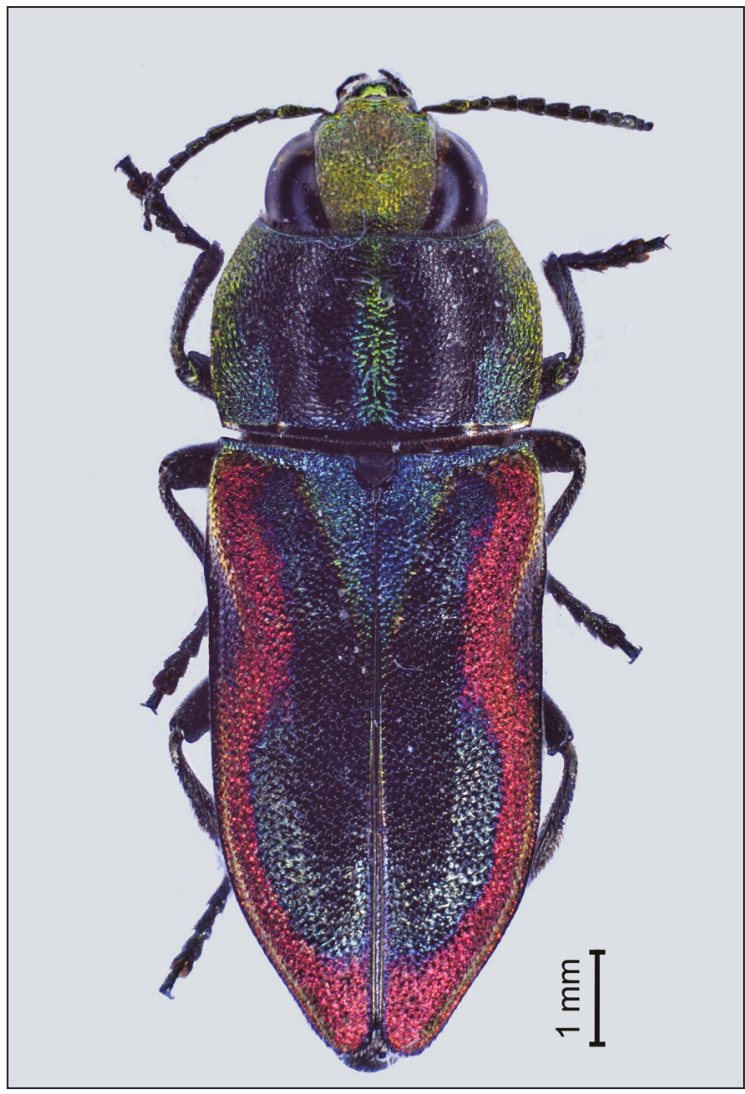

Figure 4. Specimen of Anthaxia lucens collected in Quarto di Tor Mastorta photographed with the focus-stacking technique (photo by E. Pulvirenti). of the MiBACT landscape constraint, therefore wholly including the two jewel beetle sites (Fig. 3). This would be desirable since the $A$. lucens spot in Tor Mastorta has risked the destruction several times due to various construction projects (C.R.A., 2016).

The Segni site is not included within the SPA IT6030043 "Monti Lepini".

The conservation of Prunus dulcis is essential to safeguard populations of this species, especially avoiding the removal of dead branches in which the species develops.

\section{CONCLUSIONS}

The records shown in this paper clarify the presence of $A$. lucens in the Inviolata Park and Rome Province while confirming the rediscovery of this species in Latium following more than a century of lack of data.

The occurrence of this jewel beetle in adjacent regions of Southern Italy, recently mentioned for Abruzzo (Sakalian et al., 2020), indicates that the absence of recent reports in Latium was likely caused by a scarcity of sensitive and exhaustive research.

The authors are strongly favourable to the Inviolata Park extension proposal since the new perimeter would fully include the sites of Tor Mastorta and Quarto di Tor Mastorta, where A. lucens and other interesting species live, giving to them a better protection and safeguard against exploitation. Indeed, these localities, as the rest of current and newly proposed Inviolata territories, are areas of considerable fauna and flora interest (Brocchieri et al., 2018; Cervoni et al., 2018; Crucitti et al., 2019a; b; Giardini et al., 2020).

In conclusion, the presented data must be taken into consideration for the Protected Area Management Plan (Piano d'Assetto dell'area protetta) because Guidonia Montecelio sites should not be absolutely compromised.

\section{ACKNOWLEDGEMENTS}

We are pleased to thank Daniele Baiocchi, Roberto Casalini, Maurizio Gigli, Alessio Morelli and Federico Rosso for the material determination and for the bibliographic help. We acknowledge the 


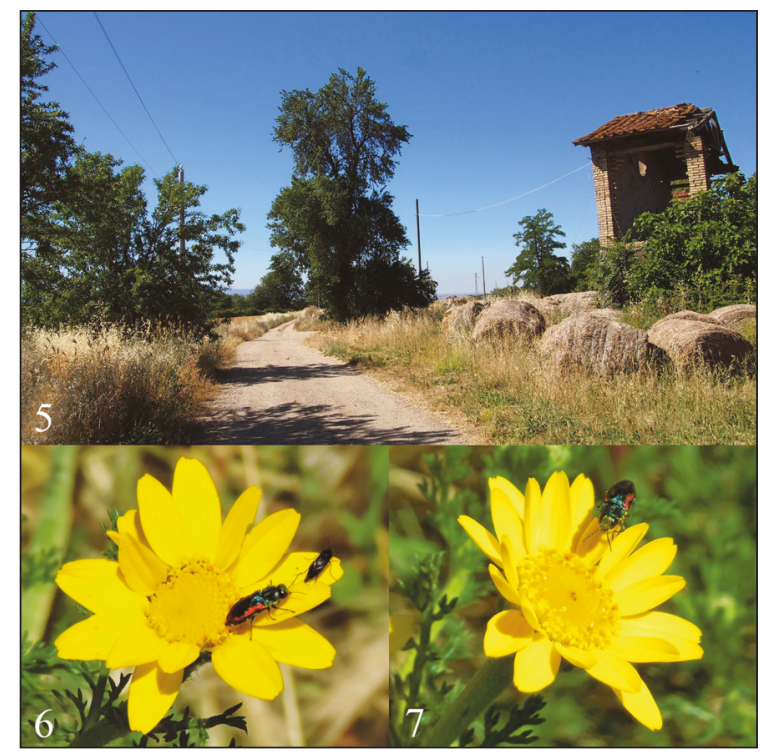

Figures 5-7. Anthaxia lucens and its Inviolata Park habitat. Fig. 5: Site of A. lucens in Tor Mastorta (photo by F. Cervoni). Fig. 6: A. lucens and a specimen of Mordellidae on Anacyclus radiatus radiatus (Asteraceae) inflorescence, 19.05.2018 (photo by E. Zacchei). Fig. 7: A. lucens on A. $r$. radiatus inflorescence, 19.05.2018 (photo by E. Pulvirenti).

members of SRSN and ANVA for their valuable support during the field research, in particular Davide Brocchieri and Leonardo Santoboni. Special thanks must be reserved to Sorinel Maimascu, that allowed the access to Tor Mastorta when necessary. Also important were the contributions of Marco Giardini for the data on the vegetation of the area and Emanuele Zacchei for the photographic documentation. We are grateful to Matteo Vommaro and Chiara Buonfrate for their cartographical and GIS support.

\section{REFERENCES}

Angelini F., 2020. Contribution to the knowledge of beetles (Insecta Coleoptera) of some protected areas of Apulia, Basilicata and Calabria (Italy). Biodiversity Journal, 11: 85-254. https://doi.org/10. 31396/Biodiv.Jour.2020.11.1.85.254

Audisio P., Baviera C., Carpaneto G.M., Biscaccianti A.B., Battistoni A., Teofili C. \& Rondinini C. (compilatori), 2014. Lista Rossa IUCN dei Coleotteri saproxilici Italiani. Comitato Italiano IUCN e Ministero dell'Ambiente e della Tutela del Territorio e del Mare, Roma, 132 pp.

Bolu H. \& Özgen İ., 2011. On the Buprestidae
(Coleoptera) species of almond orchards in the Southeastern and Eastern Anatolia in Turkey. Munis Entomology \& Zoology, 6: 970-976.

Brocchieri D., Cervoni F., Pulvirenti E. \& Crucitti P., 2018. Gli Odonati del Parco Naturale Archeologico dell'Inviolata (Guidonia Montecelio, Roma) (Odonata). Bollettino dell'Associazione Romana di Entomologia, 73: 5-21.

Cervoni F., Brocchieri D., Crucitti P., Grispigni Manetti C., Marini D., Pulvirenti E. \& Santoboni L., 2018. Prospetto della fauna del Parco Regionale Archeologico Naturale dell'Inviolata di Guidonia (Roma). Annali 2017-2018 dell'Associazione Nomentana di Storia e Archeologia: 96-101.

C.R.A. (Comitato per il Risanamento Ambientale), 2016. Dossier Regione Lazio vs Inviolata Guidonia ovvero, Cerroni dispone, la Regione esegue. Stampato in proprio, Guidonia, 108 pp.

Crucitti P., Brocchieri D., Bubbico F., Castelluccio P., Cervoni F., Di Russo E., Emiliani F., Giardini M. \& Pulvirenti E., 2019a. Checklist di gruppi selezionati dell'entomofauna del Parco Naturale Archeologico dell'Inviolata (Guidonia Montecelio, Roma) (Insecta). Bollettino della Società Entomologica Italiana, 151: 64-91. https://doi.org/10.4081/bolletti nosei.2019.65

Crucitti P., Brocchieri D., Cervoni F., Di Russo E., Giardini M., Manetti C. \& Santoboni L., 2019 b. Checklist dei Vertebrati del Parco Naturale Archeologico dell'Inviolata (Guidonia Montecelio, Roma). XLII contributo allo studio della biodiversità della Campagna Romana a nord-est di Roma. Quaderni del Museo Civico di Storia Naturale di Ferrara, 7: 61-79.

Curletti G., 1994. I Buprestidi d'Italia. Monografie di Natura Bresciana No. 19, Brescia.

Curletti G., 2005. Coleoptera Buprestidae. In: Ruffo S. \& Stoch F. (Eds.), 2005. Checklist e distribuzione della fauna italiana. Memorie del Museo Civico di Storia Naturale di Verona, 2 serie, Sezione Scienze della Vita, 16: 205-206.

Forum Entomologi Italiani, 2013. Anthaxia (Anthaxia) lucens lucens Küster, 1852. Available at http://www.entomologiitaliani.net/public/forum/php BB3/viewtopic.php? $\mathrm{f}=73 \& \mathrm{t}=44555$ \&hilit=anthaxia + lucens . Accessed on 22 February 2021.

Forum Natura Mediterraneo, 2019. Buprestidae: Anthaxia candens? Sì, ssp. lucens. Available at https:// www.naturamediterraneo.com/forum/topic.asp?TOPI C_ID=312999. Accessed on 22 February 2021.

Giardini M., 2005. Cenni sull'ambiente naturale del Parco archeologico-naturale dell'Inviolata e delle tenute storiche di Guidonia-Montecelio. In: Atti del Convegno di Studi "Parco archeologico naturale dell'Inviolata di Guidonia, le ragioni di una tutela". 
Guidonia, 25 gennaio 2003. Calamita U. (a cura di), Associazione culturale onlus Amici dell'Inviolata Guidonia, Provincia di Roma, Roma, 27-55.

Giardini M., Angeloni D., Brocchieri D., Di Russo E., Tringali L. \& Crucitti P., 2020. Contributo alla conoscenza della flora del Parco Naturale Archeologico Regionale dell'Inviolata (Guidonia Montecelio, Roma). Annali del Museo Civico di Rovereto, 36: 201-252.

Gobbi G., 1986. Le piante ospiti dei Buprestidi Italiani. Primo quadro d'insieme (Coleoptera, Buprestidae). Fragmenta entomologica, 19: 169-265.

Gobbi G., 1993. I Buprestidi del Lazio (Coleoptera, Buprestidae). Bollettino dell'Associazione romana di entomologia, 47: 39-73.

Hanot S. \& San Martin G., 2019. Anthaxia candens (Panzer, 1793), espèce nouvelle pour la faune de Belgique. Lambillionea, 109: 128-132.

Küster H.C., 1852. Die Kafer Europa's: nach der Natur beschrieben. Verlag von Bauer \& Raspe in Nurnbergm, 24: 66-67.
Luigioni P., 1929. I Coleotteri d'Italia: catalogo sinonimico-topografico-bibliografico. Memorie della Pontificia Accademia delle Scienze, I Nuovi Lincei, Ser. 2, 13. Scuola tipografica Pio X, Roma, $1160 \mathrm{pp}$.

Mühle H., Brandl P. \& Niehuis M., 2000. Catalogus Faunae Graeciae: Coleoptera, Buprestidae. Ed. Röble, Augsburg, 254 pp.

Porta A., 1929. Fauna Coleopterorum Italica. Vol. III, Diversicornia. Stabilimento Tipografico Piacentino, Piacenza, 466 pp.

Sakalian V., Migliaccio E., Tassi F., Doychev D. \& Georgiev G., 2020. New and interesting records of jewel and longhorn beetles from Abruzzo, Lazio and Molise National Park, Italy (Coleoptera: Buprestidae and Cerambycidae). Fragmenta entomologica, 52: 63-66. https://doi.org/10.4081/fe.2020.412

Tassi F., 1962. Appunti per una migliore conoscenza dei Coleotteri Buprestidi del Lazio. Bollettino dell'Associazione romana di entomologia, 17: (1) 4$6,(2-3) 7-8$, , (4) 25-27. 